\title{
DOES ENVIRONMENTAL, SOCIAL AND GOVERNANCE PERFORMANCE INFLUENCE ECONOMIC PERFORMANCE?
}

\author{
Kemal CEK ${ }^{(\mathbb{D}}{ }^{*}$, Serife EYUPOGLU (D) \\ Business Administration Department, Faculty of Economics and Administrative Sciences, \\ Near East University, Nicosia, Turkey
}

Received 07 March 2019; accepted 13 February 2020

\begin{abstract}
The purpose of this paper is to evaluate the influence of environmental, social and governance performance on the economic performance of the Standard \& Poor's 500 companies. Structural equation modeling and linear regression have been utilized to measure the overall and individual influence of environmental, social and governance (ESG) performance on economic performance using longitudinal data comprising the years from 2010 to 2015. The overall ESG model had a significant relationship on economic performance. Furthermore, the findings of this study show that social and governance performance significantly affects economic performance in all regression models. However, environmental performance failed to show a significant relationship. The research contributes to the literature by providing insights for investors, managers and employees about the influence of ESG performance on company performance.
\end{abstract}

Keywords: corporate social responsibility, economic performance, environmental performance, governance performance, social performance, structural equation modelling.

JEL Classification: E00, G3, Q0.

\section{Introduction}

Financial crises and disputes have increased apprehensions over companies' transparency, reputation, ethical, social and environmental performance (Galbreath, 2013; Nicholson \& Kiel-Chisholm, 2011). In addition, media pressure has played a critical role in motivating companies towards increased ESG transparency and disclosure (Garcia-Sanchez et al., 2014). Customers, investors, government, and employees are the key stakeholders which contribute to the growing interest on the socially responsible aspects (Schwartz \& Carroll, 2003). Beyond that, sustainability issues have attracted intensified attention by the stakeholders and scholars. Therefore, firms' ESG disclosures have substantially increased to meet the stakeholders' demands and create more accountability for firms (Eccles et al., 2014; Tamimi \& Sebastianelli, 2017). Over the $21^{\text {st }}$ century the competitive nature of the business environment requires a

*Corresponding author. E-mail: kemal.cek@neu.edu.tr 
range of practices to achieve a competitive advantage. Furthermore, the Principles for Responsible Investment (PRI) make the link between environmental, social and governance (ESG) and investment performance prominent. Firms from more than 150 countries agree on the United Nations' Global Impact Signatory which covers topics such as human rights, environment, transparency, and worker rights. It is stated that Northern Europe makes up most of the signatories in the UN Global Compact, however; U.S. was the most represented country as a single country. Socially responsible investment reached higher levels in the U.S. with \$3.74 trillion with philanthropic activities and use of codes of ethics being higher in the U.S than in other countries. There is a growth in the demand and emphasis placed on the socially responsible aspects by the stakeholders (Tamimi \& Sebastianelli, 2017). In line with these arguments, stakeholder theory argues that firms must operate by considering the needs of all stakeholders that are involved in the business activities of the firm. ESG performance is a way of considering the needs of stakeholders in terms of environmental, social and governance initiatives and providing them with the information they demand regarding these issues. Thus, satisfaction and dissatisfaction among stakeholders and influence the economic performance of the companies (Clarkson, 1995).

Discussions of ESG performance have shifted from the traditional financial perspective to a more sophisticated perspective of socio-economic outcomes (Wang et al., 2016). ESG information offers relevant information regarding non-financial performance of a company. Companies provide information about their technology, raw materials, adherence with regulations, strategies and contributions to the society (van Duuren et al., 2016). Within the sustainability and business ethics literature the concept of ESG and its consequences had been intensely researched. Results on the relationship between ESG and firm performance yield different findings. Some studies concluded that there is a positive relationship between ESG and firm performance (Fatemi et al., 2018; Yoon et al., 2018; Zhao et al., 2018); while others concluded a negative relationship or no relationship at all (Atan et al., 2018; Duque-Grisales \& Aguilera-Caracuel, 2019; Malcolm et al., 2007). Furthermore, geographical area makes a difference amongst firms with research conducted in different regions yielding different findings which make it challenging to present a decisive conclusion (Forte, 2013; Lambooy, 2010). Despite the intense attention paid by scholars on financial outcomes of the ESG (Gallego-Alvarez et al., 2014; Lo \& Kwan, 2017; Mervelskemper \& Streit, 2017), the inquiry to find evidence for the impact of ESG on the economic performance remains unanswered. Thus, economic performance has received less attention than financial performance. There has been an increase in the multiplicity of regions and countries appearing within the research samples. This can be both explained by globalization and the use of institutional view while analyzing the ESG aspects (Pache \& Santos, 2013; Surroca et al., 2010). There is a gap within the subject as the causality between economic performance and sustainability performance is still a complex subject (Friede et al., 2015; Margolis \& Walsh, 2003; Taliento et al., 2019). Furthermore, several studies investigated the association between ESG performance and financial performance of the companies; however, the results were ambiguous and inconclusive (Horváthová, 2010; Landi \& Sciarelli, 2019; Revelli \& Viviani, 2015; van Beurden \& Gössling, 2008). This study aims to fill these gaps by providing an evaluation of the causal effect of ESG on the economic performance of firms and to provide conclusive findings on the subject. 
In this respect the purpose of this study is two-fold: first, investigating the influence of ESG performance on the economic performance of U.S. firms; second, investigating the individual influences of environmental, social and governance performance on the economic performance of the firms. The stakeholder theory is used as a framework to explain the proposed relationship between the variables. The empirical analysis was carried out using longitudinal data (20102015) from the U.S. Structural equation modelling (SEM) and multiple regression analysis were employed using lagged values for ESG performance to claim causality.

The remainder of the paper is organized as follows. Section 1 consists of the theoretical and hypotheses development in light of the literature. Section 2 presents the methodology of the research and the results are presented in section 3. Discussion is carried out in section 4 and the final section concludes the paper.

\section{Hypothesis development}

The concept of ESG covers operations and behaviors of a company on environmental, social and governance matters (Bassen \& Kovacs, 2008). Furthermore, ESG disclosure increases transparency within the company about their environmental, social and governance practices (Eccles et al., 2014; Li et al., 2018). Disclosure of these aspects creates more incentives for managers, investors and stakeholder to make better decisions and evaluations. Therefore, ESG disclosure causes an increase in the availability and quality of the information (Cheng et al., 2014). This is expected to reduce the information asymmetry between firm and stakeholders (El Ghoul et al., 2011). ESG investing is not the same as strategic management; however, successful management and accounting of ESG requires a strategic point of realization of the concept. According to van Duuren et al. (2016) ESG management affects the technology, resources, employees, and society in the long-term.

ESG information is used by investors in making decisions about the companies' economic performance (Amel-Zadeh \& Serafeim, 2018). In addition, ESG information is claimed to be a measure of opportunities and risks (Limkriangkrai et al., 2017). According to Russo and Perrini (2010), from the stakeholder theory view, stakeholders' primary interests are environmental, social and governance issues. There is a link between ESG performances of organizations and their economic performances which has been created by the perceptions of the stakeholders (Barnett, 2007). According to Fisman, Heal, and Nair (2006), social performance can boost companies' ability in gaining competitive advantage and increasing market value. Clarkson (1995) claimed that companies' ability in contributing to stakeholders' demands is the key to economic performance. Given the concept of ESG studied as a single construct the previous findings are rather inconclusive or misleading. Some scholars suggested that there is a positive relationship between considering the needs of stakeholders and financial and economic performance (Nekhili et al., 2019; Richardson, 2009; Tarmuji et al., 2016). El Ghoul, Guedhami, and Kim (2017) analyzed the relationship between ESG performance and firm value in 53 countries and found a positive relationship. Furthermore, Friede et al. (2015) conducted a meta-analysis indicated that vast majority of the research found a positive association between ESG and financial performance. Therefore, the following hypothesis is proposed: 
H1 ESG performance has a positive influence on economic performance.

Environmental issues caused by companies such as greenhouse gas emissions, water management, and air pollution have gained the attention of all countries (Li \& Green, 2011). There are several arguments on the relationship between environmental performance and economic performance. To start with, carrying out business operations that comply with environmental regulations would minimize the future costs of not complying with the regulations (Hart, 1995; Shrivastava, 1995). Likewise, considering an environmentally friendly business strategy, operating costs can also be reduced (Russo \& Fouts, 1997). In a normative stakeholder perspective, customers would perceive firms' products and services in a positive way (Donaldson \& Preston, 1995). In general, employees, customers and government, which are key stakeholders, can positively react to the environmentally friendly image created by firms and therefore develop positive attitudes (Berman et al., 1999; Hart, 1995). Al-Najjar and Anfimiadou (2011), found a positive relationship between environmental performance and market-based performance in a sample of $350 \mathrm{UK}$ companies. Wang, Li, and Gao (2014) analyzed the effect of greenhouse gas emission disclosure on the Tobin's Q and found a negative effect in Australia through the perspective of stakeholder theory. This suggests that stakeholder respond negatively to activities which harms the environment such as greenhouse gas emissions. Furthermore, Yadav, Han, and Rho (2016) found a positive relationship between environmental performance and abnormal stock returns on a sample of 394 US companies using efficient market theory. Therefore, companies that engage in environmentally responsible business operations can create affirmative stakeholder perceptions resulting in improved economic performance (Baumgartner, 2014; Branco \& Rodrigues, 2007; Epstein \& Schnietz, 2002). In line with the previous arguments the following hypothesis is proposed:

H2 Environmental performance has a positive influence on economic performance.

Stakeholders consider the social initiatives of companies such as employee and customer related aspects (Rhouma et al., 2012). Concepts such as human rights and supply chain issues have gained attention due to the globalized companies and supply chains and the U.S is one of the leading countries in this field (Darragh, 2011; Tschopp, 2005). For instance, California applied the California Transparency in Supply Chains Act of 2010 and at the federal government level a similar act is aimed to be proposed (Darragh, 2011). According to Gao and Bansal (2013) benefits of such practices include economic and financial advantages. Employees are one of the major groups of stakeholders; therefore, firms' way of managing and maintaining relationships with employees can influence their economic performance (Delery \& Doty, 1996). Furthermore, investing in human resource management practices can assist a business to realize human resource related benefits and enhance competitive advantage for firms (Greening \& Turban, 2000). Another human resource related benefit is lower turnover, absenteeism and increased productivity (Berman et al., 1999).

Moreover, economic performance can be affected by any socially irresponsible activity of companies. According to Frooman (1997) companies faced with skeptical market reactions when they show social behaviors which might be deemed as socially irresponsible by the customers and investors. The market reactions are found to be significantly negative for these companies (Bromiley \& Marcus, 1989). According to Waddock and Graves (1997) economic performance of a company can be increased through customer perceptions on product qual- 
ity and safety. Garcia-Sanchez, Prado-Lorenzo, Rodriguez-Dominguez, and Gallego-Alvarez (2008), analyzed the effect of social performance on the sales growth though a stakeholder theory perspective and found a positive effect in Spain. In addition, Mishra and Suar (2010) analyzed the effect of social performance on the return on asset as a financial performance indicator and found a positive effect in India. However, Surroca and Tribó (2008) analyzed 22 different countries and found a negative relationship between social performance and return on asset and Tobin's Q. Even though contradictory results exist, on the whole it can be said that social performance contributes to the overall economic performance of companies (Dhaliwal et al., 2011). Therefore, the following hypothesis is proposed:

H3 Social performance has a positive influence on economic performance.

The corporate governance structure of a company includes, among others, board functions and structure, compensations policy, company vision and strategy and rights given to shareholders. Moreover, companies show voluntary disclosures of corporate governance information to increase transparency and minimize agency issues (Allegrini \& Greco, 2013). Corporate governance performance is associated with many economic performance indicators including resource usage, attracting investment capital, and promoting investors' trust. In addition, corporate governance performance enhances firms' ability to pay attention to societal issues and stakeholder demands which contribute to the long-term economic performance of firms (Yoon et al., 2018). Furthermore, Gill (2008) argued that governance activities can influence and shape stakeholders' perceptions and behaviors towards the company. Corporate governance practices also contribute to the reputation and image of a company. Therefore, managers and CEOs are willing to invest in positively perceived governance related activities to enhance sympathy towards the company and achieve a good prestige (Barnea \& Rubin, 2010). According to Klettner, Clarke, and Boersma (2014), corporate governance has an economic influence on the firms. The studies which focused on the corporate governance and the firm performance nexus, found a positive relationship between governance performance and firm performance (Bhagat \& Black, 1998; Li \& Yang, 2012; Monda \& Giorgino, 2013). Monda and Giorgino (2013) found a positive link between governance performance and financial performance indicators such as market valuation and return on asset for companies in France, Italy, UK and US. In addition, cost of equity is also reduced when companies showed improved governance performances in the US (Li \& Yang, 2012). Soana (2011) found a positive relationship between governance performance and return on assets of Italian banks. According to Driffield, Mahambare, and Pal (2007), a more shareholder-oriented governance strategy has a positive influence on capital structure and firm value. Accordingly, the following hypothesis is proposed:

H4 Governance performance has a positive influence on economic performance.

\section{Materials and methods}

In this study, longitudinal data have been used for environmental, social, governance and economic performance. The longitudinal approach was utilized because it can help analyze the causal relationship between ESG and economic performance of firms (Allouche \& Laroche, 2005). Annual data has been collected from the ASSET4 ${ }^{\circledR}$ database provided by 
Thomson Reuters Inc. It is adhered as one of the most credible and objective sources of data (Galbreath, 2013; Ortas et al., 2015). Thomson Reuters ASSET4 ${ }^{\oplus}$ provides a database about ESG performance measures. Seventy key performance indicators are classified into 18 groups which measures each of the ESG. Due to the socio-historical differences across different countries, it is inevitable to conduct a study in the U.S. ESG data have been adopted as 1-year, 2-year and 3-year lagged data therefore, and the data selected is for the years between 2010 and 2012. The chosen period is important for the U.S. companies as the assets managed under the socially responsible and sustainable investment criteria rose by 22 percent from $\$ 3.07$ trillion disclosed in 2010 to $\$ 3.74$ trillion in 2012 . In order to measure the impact, economic performance data have been selected for the years between 2011 and 2015 which allows to measure up to 3 years of lagged data for each ESG year. Therefore, for each firm 5 years of relevant data have been obtained. Global financial crisis can be adhered as a cornerstone for the ESG research and prior research about the relationship between ESG and economic performance is limited. Thus, the period after the crisis when the companies have started placing more importance and due conscience on their ESG performances considerably to enhance a strong image is an important period to analyze (Miralles-Quirós et al., 2019).

ESG is a non-financial performance measure; therefore, it differs from the traditional measures of firm performance. ESG covers a considerable amount of material non-financial information and provides additional perspectives for the investment community (Li et al., 2018). According to Eccles and Viviers (2011) there is an increasing demand for additional information which is particularly material. ESG incorporates a broad range of constructs such as environmental issues (climate change, pollution), social issues (e.g. quality, safety, human rights) and corporate governance issues (e.g. auditing, board functions, transparency, reporting). Therefore, ESG concept is an aggregated three-factor model of these dimensions. It is argued that the ESG constructs should be considered in a single study as they are interconnected with each other (Galbreath, 2013; van Duuren et al., 2016). ESG performance was measured using more than 280 performance indicators by Thomson Reuters experts. A total of 372 U.S. companies from mixed industries (e.g. technology, financial, manufacturing, logistics, and oil) listed in S\&P 500 involved in the data have been attributed a score from a scale of 0 (lowest) to 100 (highest) for their environmental, social, governance and economic performance. Environmental performance refers to firms' influence on the environmental indicators such as carbon emission, resource consumption, and product innovation. Social performance refers to firms' influence on the social indicators such as human rights, equality, health and safety, community and product responsibility. Governance performance refers to firms' influence on the board functions, structure, compensation, policy, vision and strategy. Economic performance is measured as client loyalty, shareholders loyalty and overall performance which imply the company's ability to generate long term shareholder value and sustain financial health. Previous studies mostly focused on the financial performance indicators such as return on asset, market value, share price (Taliento et al., 2019; Velte, 2017; Yoon et al., 2018). It is necessary to evaluate the financial indicators as well as non-financial indicators to provide stronger conclusions for the causality between the ESG performance and firm performance (Goyal et al., 2013). Thus, this can help to make an evaluation and generalization based on the influence of 
ESG performance on the overall economic performance of the companies (Ferrero-Ferrero et al., 2016; Goyal et al., 2013).

The data analysis consists of two parts. First, structural equation modeling was used to test H1 (whether ESG influence the economic performance). ESG is constructed as a latent variable from the manifest environmental, social and governance performance variables. Model fit, and the beta coefficients have been tested and the regression coefficients for the impact of ESG performance on the economic performance are also tested. In addition, structural relationships among latent variables can be analyzed by using SEM (Bollen \& Long, 1993). ESG is constructed as a three-factor model and its influence on the economic performance have been tested. The SEM model based on hypothesis 1 is depicted in Figure 1.

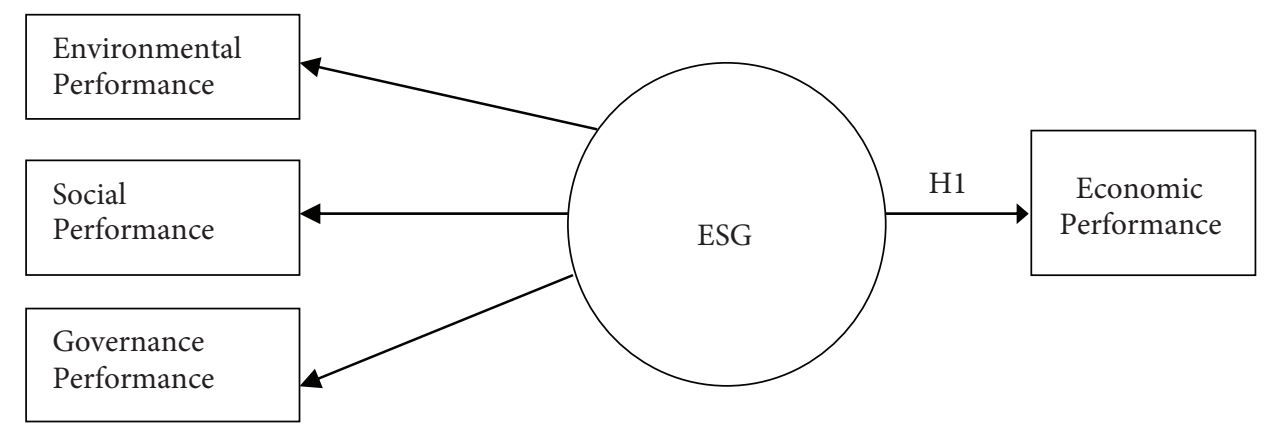

Figure 1. SEM Model

Second, multiple regression analysis was used to test the individual effects of the environmental, social and governance on the economic performance (Frooman, 1997; Horváthová, 2010). Within the regression model, the dependent variable was the economic performance and the independent variables were environmental, social and governance performance. Considering the multidimensionality of the concept (Brammer et al., 2009), there is a need to analyze the individual effects of each ESG variable. Three years of lagged ESG data were used for each year of the economic performance variable. To test the hypotheses $\mathrm{H} 2, \mathrm{H} 3$, and $\mathrm{H} 4$, nine regression analyses have been conducted as three models. The models 1-3 test the relationship between 2010-2013 ESG measures on the three consecutive years of economic performance measures.

The multiple regression models are as follows:

Economic performance $e_{t}=\beta_{0}+\beta_{1}$ Environmental performance $_{t-1,2,3}+$ $\beta_{2}$ Social performance $_{t-1,2,3}+\beta_{3}$ Governance performance $_{t-1,2,3}$.

\section{Results}

In Table 1 below, the descriptive statistics for the U.S. companies' environmental, social, and governance performances are summarized for the years between 2010 and 2013. In addition, descriptive statistics for economic performance has been provided for the years 2011 to 2015. The U.S. companies' governance performance was significantly higher than their 
environmental and social performance over the years. However, a negative trend can be observed for governance performance from 2010 to 2012. Further, environmental performance showed a positive trend from 2010 to 2012. Social performance showed a stable trend over the period. On the other hand, economic performance of the U.S. companies showed a drop in 2011 from a mean score of 66.76 to 61.91 in 2012. From 2012, a positive trend can be observed with a mean score of 72.77 in 2015. Moreover, governance performance showed lower standard deviation values than environmental and social performance. This indicates that governance performance of the U.S. companies was stable; however, their environmental and social performances were more volatile. Economic performances of the companies were more stable in 2015 than in other years.

Table 1. Descriptive Statistics of the U.S. based companies

\begin{tabular}{|c|c|c|c|c|c|c|}
\hline & $\mathrm{N}$ & Min. & Max. & Mean & $\begin{array}{c}\text { Std. } \\
\text { Deviation }\end{array}$ & Skewness \\
\hline \multicolumn{7}{|l|}{ ESG 2010} \\
\hline GOV & 372 & 4.85 & 96.42 & 77,0742 & 16,17014 & $\begin{array}{l}-1.498 \\
\end{array}$ \\
\hline ENV & 372 & 9.40 & 94.96 & 57,8988 & 32,14394 & -0.377 \\
\hline SOC & 372 & 3.74 & 97.29 & 59,5466 & 27,47565 & -0.381 \\
\hline \multicolumn{7}{|l|}{ ESG 2011} \\
\hline GOV & 372 & 5.42 & 96.62 & 76,8359 & 16,61201 & -1.318 \\
\hline ENV & 372 & 8.77 & 94.65 & 60,0239 & 31,99475 & -0.470 \\
\hline SOC & 372 & 5.01 & 97.26 & 60,7345 & 27,55730 & -0.457 \\
\hline \multicolumn{7}{|l|}{ ESG 2012} \\
\hline GOV & 372 & 6.03 & 96.38 & 74,5997 & 16,74263 & -1.133 \\
\hline ENV & 372 & 8.29 & 94.21 & 60,1922 & 31,40999 & -0.501 \\
\hline SOC & 372 & 3.60 & 97.00 & 59,1322 & 28,03563 & -0.386 \\
\hline \multicolumn{7}{|c|}{ ECN 2011-2015 } \\
\hline ECN 2011 & 372 & 2.82 & 98.09 & 66,7592 & 24,75135 & -0.712 \\
\hline ECN 2012 & 372 & 3.20 & 98.52 & 61,9117 & 27,04446 & -0.424 \\
\hline ECN 2013 & 372 & 3.39 & 98.55 & 64,0072 & 26,03603 & -0.599 \\
\hline ECN 2014 & 372 & 7.36 & 98.17 & 67,3089 & 23,44055 & -0.664 \\
\hline ECN 2015 & 372 & 17.37 & 97.03 & 72,7678 & 18,97732 & -0.814 \\
\hline
\end{tabular}

Notes: ${ }^{* *}, \mathrm{p}<0.01 ;{ }^{*}, \mathrm{p}<0.05 ; \mathrm{ECN}$, economic performance; ENV, environmental performance; SOC, social; GOV, governance performance.

Table 2 below shows the correlation coefficients for ESG and economic performance variables. The correlation coefficients implied that variables used are not highly correlated with each other. The ESG variables showed relatively higher correlations with each other however, this does not imply a multicollinearity problem. The correlations and variance inflation factor (VIF) between the variables for each of the years were tested and multicollinearity is not an obstacle in this research. 
Table 2. Correlation statistics for variables

\begin{tabular}{|c|c|c|c|c|}
\hline & GOV & ENV & SOC & ECN \\
\hline GOV & 1 & & & \\
\hline ENV & $0.64^{* *}$ & 1 & & \\
\hline SOC & $0.63^{* *}$ & $0.79^{* *}$ & 1 & \\
\hline ECN & $0.37^{* *}$ & $0.44^{* *}$ & $0.50^{* *}$ & 1 \\
\hline
\end{tabular}

Notes: ${ }^{* *}, \mathrm{p}<0.01 ;{ }^{*}, \mathrm{p}<0.05^{\star} ; \mathrm{ECN}$, economic performance; ENV, environmental performance; SOC, social; GOV, governance performance.

For a SEM analysis, it is important that the model fits the data. The model-fit indices and the impact of ESG on economic performance are shown in Table 3 below. Hu and Bentler (1999) suggested the cut-off criteria for a good model-fit as a value closer to 0.95 for comparative fit index statistic (CFI) and a cut-off value closer to .06 for root mean square error of approximation statistic (RMSEA). In addition, a cut-off value closer to 0.95 for goodness-offit statistic (GFI) has been suggested. A good model fit would be expected to provide results for Chi-square test to be insignificant (Barnett, 2007). Table 3 below summarizes the modelfit indices for the nine models formed and the factor loadings of the three-factor ESG model on the economic performance. Considering the criteria, the models 1 to 8 showed good fit indices. Thus, the model-fit of the 8 models were accepted. However, model 9, showed

Table 3. SEM Results and Model Fit Indices of the U.S. based companies

\begin{tabular}{|l|c|c|c|c|c|c|c|}
\hline \multicolumn{1}{|c|}{ Model Fit Indices } & CFI & GFI & RMSEA & $\begin{array}{c}\text { CMIN/ } \\
\text { df }\end{array}$ & $\begin{array}{c}\text { Factor Loadings } \\
\text { of Laged ESG } \\
\text { on ECN }\end{array}$ & $\mathrm{R}^{2}$ & Sig. \\
\hline $\begin{array}{l}\text { Model 1 } \\
\text { 2010 ESG-2011 ECN }\end{array}$ & 0.995 & 0.992 & 0.077 & 3.159 & 0.66 & $47.4 \%$ & $* *$ \\
\hline $\begin{array}{l}\text { Model 2 } \\
\text { 2010 ESG-2012 ECN }\end{array}$ & 0.999 & 0.996 & 0.031 & 1.352 & 0.72 & $46.3 \%$ & $* *$ \\
\hline $\begin{array}{l}\text { Model 3 } \\
\text { 2010 ESG-2013 ECN }\end{array}$ & 0.999 & 0.997 & 0.027 & 1.271 & 0.59 & $32.9 \%$ & $* *$ \\
\hline $\begin{array}{l}\text { Model 4 } \\
\text { 2011 ESG-2012 ECN }\end{array}$ & 0.997 & 0.995 & 0.050 & 2.088 & 0.74 & $47.4 \%$ & $* *$ \\
\hline $\begin{array}{l}\text { Model 5 } \\
\text { 2011 ESG-2013 ECN }\end{array}$ & 0.997 & 0.995 & 0.050 & 1.970 & 0.50 & $31.8 \%$ & $* *$ \\
\hline $\begin{array}{l}\text { Model 6 } \\
\text { 2011 ESG-2014 ECN }\end{array}$ & 0.994 & 0.991 & 0.079 & 3.323 & 0.50 & $24.6 \%$ & $* *$ \\
\hline $\begin{array}{l}\text { Model 7 } \\
\text { 2012 ESG-2013 ECN }\end{array}$ & 0.997 & 0.995 & 0.049 & 1.975 & 0.59 & $34.3 \%$ & $* *$ \\
\hline $\begin{array}{l}\text { Model 8 } \\
\text { 2012 ESG-2014 ECN }\end{array}$ & 0.997 & 0.995 & 0.048 & 1.884 & 0.52 & $27 \%$ & $* *$ \\
\hline $\begin{array}{l}\text { Model 9 } \\
\text { 2012 ESG-2015 ECN }\end{array}$ & 0.998 & 0.987 & 0.101 & 5.183 & 0.48 & $23.4 \%$ & $* *$ \\
\hline
\end{tabular}

Notes: ${ }^{* *}, \mathrm{p}<0.01 ;{ }^{*}, \mathrm{p}<0.05 ; \mathrm{ECN}$, economic performance; ESG, environmental, social and governance performance. 
RMSEA value above 1 which indicates a poor fit. Although CFI, GFI and CMIN/df showed good model fit, RMSEA is accepted as the most informative goodness of fit indices; therefore, model 9 was rejected (relationship between 2012 ESG and 2015 economic performance).

To test hypothesis 1, whether ESG has an impact on economic performance, structural equation modelling is used. The results showed that ESG and economic performance showed significant loading coefficients over the proposed years. Moreover, the $\mathrm{R}^{2}$ for each model showed that three-factor ESG explained a considerable variance in economic performance. It should be noted that the highest amount of variance in economic performance is explained in the 1-year lagged models. Therefore, hypothesis 1 was accepted (ESG performance has a positive influence on economic performance).

Table 4. Multiple Regression Results of the U.S. based companies

\begin{tabular}{|c|c|c|c|}
\hline $\begin{array}{c}\text { Model } 1 \\
\text { Predictors } 2010 \text { ESG }\end{array}$ & $\begin{array}{l}2011 \text { ECN } \\
\text { (1-Year Lag) }\end{array}$ & $\begin{array}{l}2012 \text { ECN } \\
\text { (2-Year Lag) }\end{array}$ & $\begin{array}{c}2013 \text { ECN } \\
\text { (3-Year Lag) }\end{array}$ \\
\hline GOV coefficient & $0.178^{\star *}$ & $0.146^{*}$ & $0.145^{*}$ \\
\hline ENV coefficient & 0.086 & $0.145^{\star}$ & 0.112 \\
\hline SOC coefficient & $0.460^{\star \star}$ & $0.421^{\star *}$ & $0.348^{\star \star}$ \\
\hline F statistic & 96.138 & 90.451 & 53.064 \\
\hline F sig. & $* *$ & $* *$ & $* *$ \\
\hline $\mathrm{R}^{2}$ & $44.3 \%$ & $42.8 \%$ & $30.5 \%$ \\
\hline Adjusted- $\mathrm{R}^{2}$ & $43.9 \%$ & $42.4 \%$ & $30 \%$ \\
\hline $\begin{array}{l}\text { Model } 2 \\
2011 \text { ESG }\end{array}$ & $\begin{array}{l}\text { 2012 ECN } \\
\text { (1-Year Lag) }\end{array}$ & $\begin{array}{c}2013 \text { ECN } \\
\text { (2-Year Lag) }\end{array}$ & $\begin{array}{c}2014 \mathrm{ECN} \\
\text { (3-Year Lag) }\end{array}$ \\
\hline GOV coefficient & $0.143^{*}$ & $0.146^{\star}$ & $0.159^{\star}$ \\
\hline ENV coefficient & 0.128 & 0.077 & -0.004 \\
\hline SOC coefficient & $0.443^{* *}$ & $0.367^{\star *}$ & $0.366^{* *}$ \\
\hline F statistic & 93.838 & 50.926 & 37.508 \\
\hline F sig. & $* *$ & ** & $* *$ \\
\hline $\mathrm{R}^{2}$ & $43.5 \%$ & $29.4 \%$ & $23.5 \%$ \\
\hline Adjusted- $\mathrm{R}^{2}$ & $43 \%$ & $28.9 \%$ & $22.9 \%$ \\
\hline $\begin{array}{l}\text { Model } 3 \\
2012 \text { ESG }\end{array}$ & $\begin{array}{c}\text { 2013 ECN } \\
\text { (1-Year Lag) }\end{array}$ & $\begin{array}{c}2014 \text { ECN } \\
\text { (2-Year Lag) }\end{array}$ & $\begin{array}{c}2015 \mathrm{ECN} \\
\text { (3-Year Lag) }\end{array}$ \\
\hline GOV coefficient & $0.120^{*}$ & 0.084 & $0.145^{\star}$ \\
\hline ENV coefficient & 0.049 & 0.023 & -0.094 \\
\hline SOC coefficient & $0.438^{\star *}$ & $0.425^{\star *}$ & $0.451^{\star *}$ \\
\hline F statistic & 57.314 & 41.331 & 36.067 \\
\hline F sig. & $* *$ & $* *$ & $* *$ \\
\hline $\mathrm{R}^{2}$ & $31.8 \%$ & $25.2 \%$ & $23.3 \%$ \\
\hline Adjusted- $\mathrm{R}^{2}$ & $31.3 \%$ & $24.6 \%$ & $22.7 \%$ \\
\hline
\end{tabular}

Notes: ${ }^{\star *}, \mathrm{p}<0.01 ;{ }^{*}, \mathrm{p}<0.05$; ECN, economic performance; GOV, governance performance; SOC, social performance; ENV, environmental performance. 
To test the individual impacts of environmental, social and governance on economic performance multiple regression analyses have been employed. Table 4 below shows the regression results for the influence of 1-year lagged, 2-year lagged, and 3-year lagged environmental, social and governance performance on the economic performance for the years 2011-2015. F-statistics indicated that the models were significant $(\mathrm{p}<0.01)$. For each lagged ESG performance, 3 regression analyses were conducted to test the influence on the economic performance.

Environmental performance only showed a significant $(\mathrm{p}<0.05)$ relationship in the 2010 ESG and 2012 ECN. However, environmental performance did not show a significant ( $\mathrm{p}<$ 0.05 ) relationship with the economic performance in the other models. Therefore, hypothesis 2 is not accepted (Environmental performance has a positive impact on economic performance). Further, 1-year lagged, 2-year lagged, and 3-year lagged social performance showed a significant $(\mathrm{p}<0.01)$ relationship with economic performance measures. Therefore, hypothesis 3 is fully supported and accepted (Social performance has a positive influence on economic performance). Moreover, governance performance showed a significant $(\mathrm{p}<0.05$ and $\mathrm{p}<0.01$ ) influence on the economic performance in 8 of the 9 regression analyses. Therefore, hypothesis 4 is accepted (Governance performance has a positive influence on economic performance). In model 1 , the adjusted $\mathrm{R}^{2}$ was $43.9 \%$ with 1 -year lag, $42.4 \%$ with 2-year lag, and 30\% with 3-year lag. In model 2, the adjusted $\mathrm{R}^{2}$ was $43 \%, 28.9 \%$ and $22.9 \%$ respectively for $1-3$ years lagged data. In model 3, the adjusted $\mathrm{R}^{2}$ was $31.3 \%, 24.6 \%$ and $22.7 \%$ respectively for $1-3$ years lagged data. It can be observed that as the number of lagged years increased, the amount of variance explained in economic performance decreased in all models. Overall, environmental, social and governance performance explain a considerable amount of variance of the economic performance of the U.S. companies.

\section{Discussion}

The key driver behind the move towards the interest in ESG performance is the perceived need to provide stakeholder with a complete picture of companies. Stakeholders' awareness and demand on the ESG is growing and they incorporate ESG information with other investment information. Companies are consolidating ESG information into their managerial and operational initiatives (Adams \& Frost, 2008). In addition, satisfying the needs of the stakeholders would yield better economic and financial performance measures (Donaldson \& Preston, 1995). Economic performance includes employee-related aspects such as motivation and retention (Greening \& Turban, 2000), customers satisfaction, loyalty (Dawkins \& Lewis, 2003), increased reputation (Whooley, 2004) and better access to capital (Roberts \& Downing, 2002). In fact, Wagner and Schaltegger (2004) discovered that companies which adopted a long-term value-oriented approach had a stronger relationship than companies without a value-oriented approach. The findings of this study showed that social and governance performance had a positive influence on economic performance of the S\&P 500 firms. However, environmental performance of the firms did not show a significant effect.

In the context of the U.S. firms listed in S\&P 500, descriptive statistics implied that, there is a negative trend in the governance performance of companies, a stable trend for 
social performance and a positive trend for environmental and economic performance. In addition, governance performance was the most stable measure in comparison with social and environmental performance measures. This implies that the S\&P 500 firms may share a similar agenda for corporate governance however, different for environmental and social operations (Nollet et al., 2016). The findings of this study indicated that environmental, social and governance performance loaded significantly on the construct of ESG performance. Therefore, ESG is confirmed as a significant construct and showed a significant influence on the economic performance between the period 2010 and 2014. A substantial amount of empirical studies found a significant relationship between ESG and economic performance (Ambec \& Lanoie, 2008; Ferrero-Ferrero et al., 2016; Velte, 2017; Yoon et al., 2018; Zhao et al., 2018) while some found an insignificant relationship (Landi \& Sciarelli, 2019; Margolis \& Walsh, 2003). Thus, the findings are in-line with previous results that found a positive association between ESG performance and economic performance measures (El Ghoul et al., 2017; Friede et al., 2015).

In the context of the U.S. environmental performance is found to have a positive influence on the financial performance of firms (Al-Najjar \& Anfimiadou, 2011; Gallego-Alvarez et al., 2014; Yadav et al., 2016). However, the findings of this research found that environmental performance did not have a significant effect. The findings of this research failed to provide support for the previous studies which found a significant positive or negative effect of environmental performance on the economic performance (Al-Najjar \& Anfimiadou, 2011; Wang et al., 2014; Yadav et al., 2016). Muhammad, Scrimgeour, Reddy and Abidin (2015) found a significant relationship between environmental performance prior to the financial crisis in 2008 and an insignificant relationship during and after the financial crisis in Australia. The findings of this study on economic performance are in line with the finding of Muhammad et al. (2015). In addition, the findings supported the studies which concluded that social performance has a positive influence on the economic performance (Dhaliwal et al., 2011; Mishra \& Suar, 2010; Surroca \& Tribó, 2008). The results also indicated that governance performance is a significant contributor of the economic performance of firms. This is in-line with the previous studies that found a positive association between the governance performance and economic performance (Klettner et al., 2014; Monda \& Giorgino, 2013; Soana, 2011).

There are various findings within the literature considering the nexus. For instance, Tarmuji et al. (2016) concluded that governance performance was the only ESG construct which showed a relationship with economic performance in Malaysian companies. In an Australian context, Sila and Cek (2017) found a significant relationship of two dimensions of the ESG namely social and environmental performance with economic performance. Governance performance of companies listed in Australia did not show a significant relationship with economic performance (Sila \& Cek, 2017). Velte (2017) found a positive relationship between ESG performance and return on assets of firms from Germany. For instance, Galema, Platinga and Scholtens (2008) found an insignificant relationship between sustainability indicators and financial risk and return over 289 companies in the U.S. Mixed results have been found in a meta-analysis study consisting of empirical research about environmental performance and economic performance (Wagner et al., 2002). According to Holder-Webb, Cohen, Nath, 
and Wood (2009) U.S. companies consider social aspects more than other aspects and tend to disclose social performance information more. In line with this finding, social performance showed a stronger influence on economic performance than governance and environmental performance. Furthermore, both the three-factor ESG and individual environmental, social and governance performance explained a considerable amount of variance in economic performance in each period. However, it is observed that 1-year lag explained a higher variance than 2-year and 3-year lag. Therefore, it can be said that the influence of environmental, social and governance performance can be observed in the following year and the extent of influence decreases in the second and third years respectively.

\section{Conclusions}

The purpose of this study is two-fold: first, forming a three-factor ESG model and test its influence on the economic performance; second, analyzing the individual influences of environmental, social and governance performance on the economic performance of the U.S. firms. In this study, data from the Asset $4^{\oplus}$ dataset have been utilized to test the proposed effects and relationships. The findings of this study are in line with the proposed influence of ESG on the economic performance. We found significant influence of ESG on the economic performance. Moreover, social and governance performance showed a significant influence on the economic performance. However, environmental performance showed an insignificant influence. Social performance is proven to be a valuable predictor of the economic performance. Another finding of this research is that governance performances of firms are higher than their environmental and social performance.

Thus, ESG is a significant predictor of the economic performance of the companies. However, it could be argued within a stakeholder theory perspective that stakeholders acknowledge social and governance performance of companies more than their environmental performance. Companies should consider the findings of this research and place importance on social and governance performance indicators to see future economic benefits. Findings also reveal that the extent of the influence of environmental, social and governance performance is highest at the year after and decreases thereafter.

This study contributes to the literature by using longitudinal data to claim causality of the findings. Therefore, causality which is a common limitation for studies which use crosssectional data has been overcome. Previous studies mostly focus on the ESG performance of European or Asia Pacific countries; however, this research focused on the U.S. In addition, another perspective for the ESG and economic performance literature by proposing both a combined three-factor model and separate factor models was provided. Findings also support that firms from different regions have different choices, policies and objectives; therefore, different findings should be expected.

The implications and suggestions for scholars include the need for additional research in different regions using longitudinal ESG data. Moreover, companies should acknowledge the importance of ESG performance and aim to achieve higher performances. For the academics, this is the first study to confirm the three-factor construct of ESG by using confirmatory factor analysis. Thus, this can provide incentives for other researches to conduct the same 
analysis across different countries and industries. This study provides insights for the management of companies. The findings are expected to provide an incentive for the companies to increase their ESG performance and enhance the transparency by disclosing ESG performance. Environmental performance of companies should be analyzed in-depth in order to understand why it is not significant in influencing the economic performance. Moreover, companies should focus more on the governance and social performances as they are proven to be significant contributors of the economic performance of companies.

Despite its relevance and contribution, this study also has some limitations. In this study, research was solely focused on the U.S. which is a developed country; this has limited the generalization of the findings to the all developed and developing countries. Last, the issue of "greenwashing" stays as a limitation for all sustainability research which based their data from the ESG information provided by companies. As a future research suggestion a developing country may be selected to compare the findings between developed and developing countries would help overcome the limitations of generalizability. Furthermore, another research suggestion is to analyze the period from 2015 to 2019 and to compare the results with the current studies. In addition, different economic indicators and mediating variables can be used to observe their effect on the relationship.

\section{Acknowledgements}

The authors thank the editor and reviewers for their comments and suggestions.

\section{Funding}

This research received no specific grant from any funding agency in the public, commercial, or not - for - profit sectors.

\section{Author contributions}

Kemal Cek was responsible for writing, data analysis and interpretation. Serife Z. Eyupoglu supervised the research and contributed to the theoretical development and editing of the article.

\section{Disclosure statement}

The authors declare that we did not have any competing financial, professional, or personal interests from other parties.

\section{References}

Adams, C. A., \& Frost, G. R. (2008). Integrating sustainability reporting into management practices. Accounting Forum, 32(4), 288-302. https://doi.org/10.1016/j.accfor.2008.05.002 
Allegrini, M., \& Greco, G. (2013). Corporate boards, audit committees and voluntary disclosure: Evidence from Italian listed companies. Journal of Management \& Governance, 17(1), 187-216. https://doi.org/10.1007/s10997-011-9168-3

Allouche, J., \& Laroche, P. (2005). A Meta-analytical investigation of the relationship between corporate social and financial performance [Post-Print]. https://econpapers.repec.org/paper/haljournl/hal00923906.htm

Al-Najjar, B., \& Anfimiadou, A. (2011). Environmental policies and firm value. Business Strategy and the Environment, 21(1), 49-59. https://doi.org/10.1002/bse.713

Ambec, S., \& Lanoie, P. (2008). Does it pay to be green? A systematic overview. Academy of Management Perspectives, 22(4), 45-62. https://doi.org/10.5465/amp.2008.35590353

Amel-Zadeh, A., \& Serafeim, G. (2018). Why and how investors use ESG information: Evidence from a global survey. Financial Analysts Journal, 74(3), 87-103. https://doi.org/10.2469/faj.v74.n3.2

Atan, R., Alam, M. M., Said, J., \& Zamri, M. (2018). The impacts of environmental, social, and governance factors on firm performance: Panel study of Malaysian companies. Management of Environmental Quality: An International Journal, 29(2), 182-194.

https://doi.org/10.1108/MEQ-03-2017-0033

Barnea, A., \& Rubin, A. (2010). Corporate social responsibility as a conflict between shareholders. Journal of Business Ethics, 97(1), 71-86. https://doi.org/10.1007/s10551-010-0496-Z

Barnett, M. L. (2007). Stakeholder influence capacity and the variability of financial returns to corporate social responsibility. The Academy of Management Review, 32(3), 794-816. https://doi.org/10.2307/20159336

Bassen, A., \& Kovacs, A. M. M. (2008). Environmental, social and governance key performance indicators from a capital market perspective (SSRN Scholarly Paper No. ID 1307091). Social Science Research Network, Rochester, NY. https://papers.ssrn.com/abstract=1307091

Baumgartner, R. J. (2014). Managing corporate sustainability and CSR: A conceptual framework combining values, strategies and instruments contributing to sustainable development. Corporate Social Responsibility and Environmental Management, 21(5), 258-271. https://doi.org/10.1002/csr.1336

Berman, S. L., Wicks, A. C., Kotha, S., \& Jones, T. M. (1999). Does stakeholder orientation matter? The relationship between stakeholder management models and firm financial performance. The Academy of Management Journal, 42(5), 488-506. https://doi.org/10.2307/256972

Bhagat, S., \& Black, B. S. (1998). The non-correlation between board independence and long-term firm performance (SSRN Scholarly Paper No. ID 133808). Social Science Research Network, Rochester, NY. https://papers.ssrn.com/abstract=133808

Bollen, K. A., \& Long, J. S. (1993). Testing structural equation models. SAGE.

Brammer, S., Brooks, C., \& Pavelin, S. (2009). The stock performance of America's 100 Best Corporate Citizens. The Quarterly Review of Economics and Finance, 49(3), 1065-1080. https://doi.org/10.1016/j.qref.2009.04.001

Branco, M. C., \& Rodrigues, L. L. (2007). Positioning stakeholder theory within the debate on corporate social responsibility. Electronic Journal of Business Ethics and Organization Studies, 12(1), 5-15.

Bromiley, P., \& Marcus, A. (1989). The deterrent to dubious corporate behavior: Profitability, probability and safety recalls. Strategic Management Journal, 10(3), 233-250. https://doi.org/10.1002/smj.4250100304

Cheng, B., Ioannou, I., \& Serafeim, G. (2014). Corporate social responsibility and access to finance. Strategic Management Journal, 35(1), 1-23. https://doi.org/10.1002/smj.2131

Clarkson, M. B. E. (1995). A stakeholder framework for analyzing and evaluating corporate social performance. The Academy of Management Review, 20(1), 92-117. https://doi.org/10.2307/258888 
Darragh, R. (2011). Coming soon: California's law on supply chain transparency. Retrieved December 21, 2018, from https://www.complianceweek.com/coming-soon-californias-law-on-supply-chaintransparency/17360.article

Dawkins, J., \& Lewis, S. (2003). CSR in stakeholder expectations: And their implication for company strategy. Journal of Business Ethics, 44(2/3), 185-193. https://doi.org/10.1023/A:1023399732720

Delery, J. E., \& Doty, D. H. (1996). Modes of theorizing in strategic human resource management: Tests of universalistic, contingency, and configurational performance predictions. Academy of Management Journal, 39(4), 802-835. https://doi.org/10.5465/256713

Dhaliwal, D. S., Li, O. Z., Tsang, A., \& Yang, Y. G. (2011). Voluntary nonfinancial disclosure and the cost of equity capital: The initiation of corporate social responsibility reporting. The Accounting Review, 86(1), 59-100. https://doi.org/10.2308/accr.00000005

Donaldson, T., \& Preston, L. E. (1995). The stakeholder theory of the corporation: Concepts, evidence, and implications. The Academy of Management Review, 20(1), 65-91. https://doi.org/10.2307/258887

Driffield, N., Mahambare, V., \& Pal, S. (2007). How does ownership structure affect capital structure and firm value? Recent evidence from East Asia1. Economics of Transition, 15(3), 535-573. https://doi.org/10.1111/j.1468-0351.2007.00291.x

Duque-Grisales, E., \& Aguilera-Caracuel, J. (2019). Environmental, Social and Governance (ESG) scores and financial performance of multilatinas: Moderating effects of geographic international diversification and financial slack. Journal of Business Ethics. https://doi.org/10.1007/s10551-019-04177-w

Eccles, N. S., \& Viviers, S. (2011). The origins and meanings of names describing investment practices that integrate a consideration of ESG issues in the academic literature. Journal of Business Ethics, 104(3), 389-402. https://doi.org/10.1007/s10551-011-0917-7

Eccles, R. G., Ioannou, I., \& Serafeim, G. (2014). The impact of corporate sustainability on organizational processes and performance. Management Science, 60(11), 2835-2857. https://doi.org/10.1287/mnsc.2014.1984

El Ghoul, S., Guedhami, O., \& Kim, Y. (2017). Country-level institutions, firm value, and the role of corporate social responsibility initiatives. Journal of International Business Studies, 48(3), 360-385. https://doi.org/10.1057/jibs.2016.4

El Ghoul, S., Guedhami, O., Kwok, C. C. Y., \& Mishra, D. R. (2011). Does corporate social responsibility affect the cost of capital? Journal of Banking \& Finance, 35(9), 2388-2406. https://doi.org/10.1016/j.jbankfin.2011.02.007

Epstein, M. J., \& Schnietz, K. E. (2002). Measuring the cost of environmental and labor protests to globalization: An event study of the failed 1999 Seattle WTO talks. The International Trade Journal, 16(2), 129-160. https://doi.org/10.1080/08853900252901396

Fatemi, A., Glaum, M., \& Kaiser, S. (2018). ESG performance and firm value: The moderating role of disclosure. Global Finance Journal, 38(C), 45-64. https://doi.org/10.1016/j.gfj.2017.03.001

Ferrero-Ferrero, I., Fernández-Izquierdo, M. Á., \& Muñoz-Torres, M. J. (2016). The effect of environmental, social and governance consistency on economic results. Sustainability, 8(10), 1005. https://doi.org/10.3390/su8101005

Fisman, R., Heal, G., \& Nair, V. B. (2006). A model of corporate philanthropy (Working Paper). Wharton School, University of Pennsylvania.

Forte, A. (2013). Corporate social responsibility in the United States and Europe: How important is it? The future of corporate responsibility. International Business and Economics Journal, 12(7), 815-824. https://doi.org/10.19030/iber.v12i7.7970

Friede, G., Busch, T., \& Bassen, A. (2015). ESG and financial performance: aggregated evidence from more than 2000 empirical studies. Journal of Sustainable Finance \& Investment, 5(4), 210-233. https://doi.org/10.1080/20430795.2015.1118917 
Frooman, J. (1997). Socially irresponsible and illegal behavior and shareholder wealth: A meta-analysis of event studies. Business \& Society, 36(3), 221-249. https://doi.org/10.1177/000765039703600302

Galbreath, J. (2013). ESG in focus: The Australian evidence. Journal of Business Ethics, 118(3), 529-541. https://doi.org/10.1007/s10551-012-1607-9

Galema, R., Plantinga, A., \& Scholtens, B. (2008). The stocks at stake: Return and risk in socially responsible investment. Journal of Banking \& Finance, 32(12), 2646-2654. https://doi.org/10.1016/j.jbankfin.2008.06.002

Gallego-Álvarez, I., García-Sánchez, I. M., \& da Silva Vieira, C. (2014). Climate change and financial performance in times of crisis. Business Strategy and the Environment, 23(6), 361-374. https://doi.org/10.1002/bse.1786

Gao, J., \& Bansal, P. (2013). Instrumental and integrative logics in business sustainability. Journal of Business Ethics, 112(2), 241-255. https://doi.org/10.1007/s10551-012-1245-2

Garcia-Sanchez, I. M., Cuadrado-Ballesteros, B., \& Sepulveda, C. (2014). Does media pressure moderate CSR disclosures by external directors? Management Decision, 52(6), 1014-1045. https://doi.org/10.1108/MD-09-2013-0446

García-Sánchez, I., Prado-Lorenzo, J., Rodríguez-Domínguez, L., \& Gallego-Álvarez, I. (2008). Social responsibility in Spain: Practices and motivations in firms. Management Decision, 46(8), 1247-1271. https://doi.org/10.1108/00251740810901417

Gill, A. (2008). Corporate governance as social responsibility: A research agenda. Berkeley Journal of International Law, 26(2), 452. https://doi.org/10.15779/Z38MS9P

Goyal, P., Rahman, Z., \& Kazmi, A. A. (2013). Corporate sustainability performance and firm performance research: Literature review and future research agenda. Management Decision. 51(2), 361-379. https://doi.org/10.1108/00251741311301867

Greening, D. W., \& Turban, D. B. (2000). Corporate social performance as a competitive advantage in attracting a quality workforce. Business \& Society, 39(3), 254-280. https://doi.org/10.1177/000765030003900302

Hart, S. L. (1995). A natural-resource-based view of the firm. The Academy of Management Review, 20(4), 986-1014. https://doi.org/10.2307/258963

Holder-Webb, L., Cohen, J. R., Nath, L., \& Wood, D. (2009). The supply of corporate social responsibility disclosures among U.S. firms. Journal of Business Ethics, 84(4), 497-527.

https://doi.org/10.1007/s10551-008-9721-4

Horváthová, E. (2010). Does environmental performance affect financial performance? A meta-analysis. Ecological Economics, 70(1), 52-59. https://doi.org/10.1016/j.ecolecon.2010.04.004

Hu, L., \& Bentler, P. M. (1999). Cutoff criteria for fit indexes in covariance structure analysis: Conventional criteria versus new alternatives. Structural Equation Modeling: A Multidisciplinary Journal, 6(1), 1-55. https://doi.org/10.1080/10705519909540118

Klettner, A., Clarke, T., \& Boersma, M. (2014). The governance of corporate sustainability: Empirical insights into the development, leadership and implementation of responsible business strategy. Journal of Business Ethics, 122(1), 145-165. https://doi.org/10.1007/s10551-013-1750-y

Lambooy, T. (2010). Institutionalisation of corporate social responsibility in the corporate governance code: The new trend of the Dutch model. In Reframing corporate social responsibility: lessons from the global financial crisis (Vol. 1, pp. 145-179). Emerald Group Publishing Limited. https://doi.org/10.1108/S2043-9059(2010)0000001013

Landi, G., \& Sciarelli, M. (2019). Towards a more ethical market: The impact of ESG rating on corporate financial performance. Social Responsibility Journal, 15(1), 11-27.

https://doi.org/10.1108/SRJ-11-2017-0254 
Li, Q., \& Green, W. (2011). Evidence of an expectation gap for greenhouse gas emissions assurance. Accounting, Auditing \& Accountability Journal, 25(1), 146-173. https://doi.org/10.1108/09513571211191789

Li, Y., \& Yang, H. I. H. (2012). Disclosure and cost of equity capital: An analysis at the market level. Research Collection School of Accountancy, 1-54. https://doi.org/10.2139/ssrn.1965663

Li, Y., Gong, M., Zhang, X.-Y., \& Koh, L. (2018). The impact of environmental, social, and governance disclosure on firm value: The role of CEO power. The British Accounting Review, 50(1), 60-75. https://doi.org/10.1016/j.bar.2017.09.007

Limkriangkrai, M., Koh, S., \& Durand, R. B. (2017). Environmental, Social, and Governance (ESG) profiles, stock returns, and financial policy: Australian evidence. International Review of Finance, 17(3), 461-471. https://doi.org/10.1111/irfi.12101

Lo, K. Y., \& Kwan, C. L. (2017). The effect of environmental, social, governance and sustainability initiatives on stock value - Examining market response to initiatives undertaken by listed companies. Corporate Social Responsibility and Environmental Management, 24(6), 606-619. https://doi.org/10.1002/csr.1431

Malcolm, S., Khadijah, Y., \& Ahmad Marzuki, A. (2007). Environmental disclosure and performance reporting in Malaysia. Asian Review of Accounting, 15(2), 185-199. https://doi.org/10.1108/13217340710823387

Margolis, J. D., \& Walsh, J. P. (2003). Misery loves companies: Rethinking social initiatives by business. Administrative Science Quarterly, 48(2), 268-305. https://doi.org/10.2307/3556659

Mervelskemper, L., \& Streit, D. (2017). Enhancing market valuation of ESG performance: Is integrated reporting keeping its promise? Business Strategy and the Environment, 26(4), 536-549. https://doi.org/10.1002/bse.1935

Miralles-Quirós, M. M., Miralles-Quirós, J. L., \& Hernández, J. R. (2019). ESG performance and shareholder value creation in the banking industry: International differences. Sustainability, 11(5), 1404. https://doi.org/10.3390/su11051404

Mishra, S., \& Suar, D. (2010). Does corporate social responsibility influence firm performance of Indian companies? Journal of Business Ethics, 95(4), 571-601. https://doi.org/10.1007/s10551-010-0441-1

Monda, B., \& Giorgino, M. (2013). Corporate governance and shareholder value in listed firms: An empirical analysis in five countries (France, Italy, Japan, UK, USA) (SSRN Scholarly Paper No. ID 2227184). https://papers.ssrn.com/abstract $=2227184$

Muhammad, N., Scrimgeour, F., Reddy, K., \& Abidin, S. (2015). The relationship between environmental performance and financial performance in periods of growth and contraction: Evidence from Australian publicly listed companies. Journal of Cleaner Production, 102, 324-332. https://doi.org/10.1016/j.jclepro.2015.04.039

Nekhili, M., Boukadhaba, A., Nagati, H., \& Chtioui, T. (2019). ESG performance and market value: The moderating role of employee board representation. The International Journal of Human Resource Management, 30, 1-27. https://doi.org/10.1080/09585192.2019.1629989

Nicholson, G. J., \& Kiel-Chisholm, S. (2011). The contribution of social norms to the Global Financial Crisis: A systemic actor focused model and proposal for regulatory change (SSRN Scholarly Paper No. ID 1943978). Social Science Research Network, Rochester, NY. https://papers.ssrn.com/abstract=1943978

Nollet, J., Filis, G., \& Mitrokostas, E. (2016). Corporate social responsibility and financial performance: A non-linear and disaggregated approach. Economic Modelling, 52, 400-407. https://doi.org/10.1016/j.econmod.2015.09.019

Ortas, E., Gallego-Alvarez, I., \& Etxeberria, I. Á. (2015). Financial factors influencing the quality of corporate social responsibility and environmental management disclosure: A quantile regression approach. Corporate Social Responsibility and Environmental Management, 22(6), 362-380. https://doi.org/10.1002/csr.1351 
Pache, A.-C., \& Santos, F. (2013). Embedded in hybrid contexts: How individuals in organizations respond to competing institutional logics. In Institutional Logics in Action, Part B (Vol. 39 Part B, pp. 3-35). Emerald Group Publishing Limited. https://doi.org/10.1108/S0733-558X(2013)0039AB014

Principles for Responsible Investment, 1. (n.d.). Integrated analysis: How investors are addressing ESG factors in fundamental equity valuation. Retrieved December 21, 2018, from https://www.unpri.org/ listed-equity/integrated-analysis-how-investors-are-addressing-esg-factors-in-fundamental-equityvaluation/153.article

Revelli, C., \& Viviani, J.-L. (2015). Financial performance of socially responsible investing (SRI): What have we learned? A meta-analysis (Post-Print). HAL.

https://econpapers.repec.org/paper/haljournl/halshs-01141295.htm

Rhouma, A. B., Francoeur, C., \& Robin, G. (2012). International corporate sustainability barometer 2012: Sustainability management in France. In Corporate sustainability in international comparison (pp. 70-93). Springer International Publishing.

Richardson, B. J. (2009). Keeping ethical investment ethical: Regulatory issues for investing for sustainability. Journal of Business Ethics, 87(4), 555-572. https://doi.org/10.1007/s10551-008-9958-y

Roberts, P. W., \& Dowling, G. R. (2002). Corporate reputation and sustained superior financial performance. Strategic Management Journal, 23(12), 1077-1093. https://doi.org/10.1002/smj.274

Russo, A., \& Perrini, F. (2010). Investigating stakeholder theory and social capital: CSR in large firms and SMEs. Journal of Business Ethics, 91, 207-221. https://doi.org/10.1007/s10551-009-0079-Z

Russo, M. V., \& Fouts, P. A. (1997). A resource-based perspective on corporate environmental performance and profitability. The Academy of Management Journal, 40(3), 534-559. https://doi.org/10.2307/257052

Schwartz, M. S., \& Carroll, A. B. (2003). Corporate social responsibility: A three-domain approach. Business Ethics Quarterly, 13(4), 503-530. https://doi.org/10.5840/beq200313435

Shrivastava, P. (1995). Environmental technologies and competitive advantage. Strategic Management Journal, 16(S1), 183-200. https://doi.org/10.1002/smj.4250160923

Sila, I., \& Cek, K. (2017). The impact of environmental, social and governance dimensions of corporate social responsibility on economic performance: Australian evidence. Procedia Computer Science, 120, 797-804. https://doi.org/10.1016/j.procs.2017.11.310

Soana, M.-G. (2011). The relationship between corporate social performance and corporate financial performance in the banking sector. Journal of Business Ethics, 104(1), 133-148. https://doi.org/10.1007/s10551-011-0894-X

Surroca, J., \& Tribó, J. A. (2008). Managerial entrenchment and corporate social performance. Journal of Business Finance \& Accounting, 35(5-6), 748-789. https://doi.org/10.1111/j.1468-5957.2008.02090.x

Surroca, J., Tribó, J. A., \& Waddock, S. (2010). Corporate responsibility and financial performance: The role of intangible resources. Strategic Management Journal, 31(5), 463-490. https://doi.org/10.1002/smj.820

Taliento, M., Favino, C., \& Netti, A. (2019). Impact of environmental, social, and governance information on economic performance: Evidence of a corporate "Sustainability Advantage" from Europe. Sustainability, 11(6), 1738. https://doi.org/10.3390/su11061738

Tamimi, N., \& Sebastianelli, R. (2017). Transparency among S\&P 500 companies: an analysis of ESG disclosure scores. Management Decision, 55(8), 1660-1680. https://doi.org/10.1108/MD-01-2017-0018

Tarmuji, I., Tarmuji, N. H., \& Maelah, R. (2016). The impact of Environmental, Social and Governance practices (ESG) on economic performance: Evidence from ESG score. International Journal of Trade, Economics and Finance, 7(3), 67-74. https://doi.org/10.18178/ijtef.2016.7.3.501

Tschopp, D. J. (2005), Corporate social responsibility: A comparison between the United States and the European Union. Corporate Social Responsibility and Environmental Management, 12(1), 55-59. https://doi.org/10.1002/csr.69 
van Beurden, P., \& Gössling, T. (2008). The worth of values - A literature review on the relation between corporate social and financial performance. Journal of Business Ethics, 82(2), 407. https://doi.org/10.1007/s10551-008-9894-x

van Duuren, E., Plantinga, A., \& Scholtens, B. (2016). ESG integration and the investment management process: Fundamental investing reinvented. Journal of Business Ethics, 138(3), 525-533. https://doi.org/10.1007/s10551-015-2610-8

Velte, P. (2017). Does ESG performance have an impact on financial performance? Evidence from Germany. Journal of Global Responsibility, 8(2), 169-178. https://doi.org/10.1108/JGR-11-2016-0029

Waddock, S. A., \& Graves, S. B. (1997). The corporate social performance-financial performance link. Strategic Management Journal, 18(4), 303-319. https://doi.org/10.1002/(SICI)1097-0266(199704)18:4<303::AID-SMJ869>3.0.CO;2-G

Wagner, M., \& Schaltegger, S. (2004). The effect of corporate environmental strategy choice and environmental performance on competitiveness and economic performance: An empirical study of EU manufacturing. European Management Journal, 22(5), 557-572. https://doi.org/10.1016/j.emj.2004.09.013

Wagner, M., Phu, N. V., Azomahou, T., \& Wehrmeyer, W. (2002). The relationship between the environmental and economic performance of firms: An empirical analysis of the European paper industry. Corporate Social Responsibility and Environmental Management, 9(3), 133-146. https:// doi.org/10.1002/csr.22

Wang, H., Tong, L., Takeuchi, R., \& George, G. (2016). Corporate social responsibility: An overview and new research directions: Thematic issue on corporate social responsibility. Academy of Management Journal, 59(2), 534-544. https://doi.org/10.5465/amj.2016.5001

Wang, L., Li, S., \& Gao, S. (2014). Do greenhouse gas emissions affect financial performance? - An empirical examination of Australian public firms. Business Strategy and the Environment, 23(8), 505-519. https://doi.org/10.1002/bse.1790

Whooley, N. (2004). Responsible business conduct, there is nothing fluffy about CSR. Accountancy Ireland, 37(2), 74-85.

Yadav, P. L., Han, S. H., \& Rho, J. J. (2016). Impact of environmental performance on firm value for sustainable investment: Evidence from large US firms. Business Strategy and the Environment, 25(6), 402-420. https://doi.org/10.1002/bse.1883

Yoon, B., Lee, J. H., \& Byun, R. (2018). Does ESG performance enhance firm value? Evidence from Korea. Sustainability, 10(10), 3635. https://doi.org/10.3390/su10103635

Zhao, C., Guo, Y., Yuan, J., Wu, M., Li, D., Zhou, Y., \& Kang, J. (2018). ESG and corporate financial performance: Empirical evidence from China's listed power generation companies. Sustainability, 10(8), 2607. https://doi.org/10.3390/su10082607 